\title{
Improving thermal stability and its effects on proton mobility inproton-conducting phosphate glasses prepared by the electrochemical substitution of sodium ions with protons
}

\author{
Takuya Yamaguchi ${ }^{\text {a }}$, TomohiroIshiyama ${ }^{\mathrm{a},}$, KanjiSakuragi $^{\mathrm{a}}$, Junji Nishii ${ }^{\mathrm{b}}$, \\ Toshiharu Yamashita $^{c}$, Hiroshi Kawazoe ${ }^{c}$, TakahisaOmata ${ }^{a}{ }^{*}$ \\ ${ }^{a}$ Division of Materials and Manufacturing Science,Graduate School of Engineering,Osaka \\ University,2-1 Yamada-oka, Suita 565-0871, Japan \\ ${ }^{b}$ Research Institute for Electronic Science, Hokkaido University, Kita 21 Nishi 10, Kita-ku, \\ Sapporo 001-0021, Japan \\ ${ }^{c}$ Kawazoe Frontier Technologies Corporation,Kuden-cho 931-113, Sakae-ku, Yokohama 247-0014, \\ Japan \\ * Corresponding author. Tel.: +81-6-6879-7462, fax: +81-6-6879-7464 \\ e-mail: omata@mat.eng.osaka-u.ac.jp \\ †Present address: Fuel Cell Materials Group, Energy Technology Research Institute, National \\ Institute of Advanced Industrial Science and Technology (AIST), AIST Central 5, Higashi 1-1-1, \\ Tsukuba, Ibaraki 305-8565, Japan
}

(C) 2015. This manuscript version is made available under the Elsevier user license http://www.elsevier.com/open-access/userlicense/1.0/ 


\begin{abstract}
We investigated electrochemical substitution involving the electrochemical oxidation of hydrogen with proton injection into an oxide glass. This was accompanied by the electrochemical reduction of sodium ions and the discharge of metallic sodium out of the glass. This is referred to as the alkali-proton substitution techniqueand we applied it to asodium-containing phosphate glass. The thermal stability of the $1 \mathrm{WO}_{3}-35 \mathrm{NaO}_{1 / 2}-8 \mathrm{NbO}_{5 / 2}-5 \mathrm{LaO}_{3 / 2}-51 \mathrm{PO}_{5 / 2}$ glass that previously deformed at $>250^{\circ} \mathrm{C}$ improved to $350{ }^{\circ} \mathrm{C}$ after alkali-proton substitution techniqueby the introduction of $\mathrm{AlO}_{3 / 2}$ and/or $\mathrm{YO}_{3 / 2}$. However, the mobility of the proton carriers decreased by $1 / 20-1 / 50$ by the introduction of $\mathrm{AlO}_{3 / 2}$ and/or $\mathrm{YO}_{3 / 2}$ whilethe thermal stability improved.Based on infrared absorption spectra the reduced mobility can beattributed to the increase inprotons that are tightly bound to oxygen byweak hydrogen bondings.
\end{abstract}

\title{
Keywords
}

proton conductor, electrochemical process, alkali-proton substitution, FT-IR, fuel cells 


\section{Introduction}

Intermediate temperature fuel cells (IT-FCs) that are operated at $300-500^{\circ} \mathrm{Chave}$ recently attracted much attention because they have advantages of cost, energy efficiency, and operating conditions compared with conventional solid oxide and polymer electrolyte fuel cells [1-3]. Many research groups have explored solid proton conductors applicable to electrolytes in IT-FCs. Electrical conductivity of $>1 \times 10^{-2} \mathrm{Scm}^{-1}$ at intermediate temperatures are required for the proton-conductingelectrolytes in ITFCs; however, such a material has not been fully developed yet.

We recently developed a technique to inject carrier protons into oxide glass by the electrochemical substitution of alkali ions in the glass with protons at high temperatures. We refer to this as the alkali-proton substitution (APS) technique [4,5]. By applying this technique to $35 \mathrm{NaO}_{1 / 2}-1 \mathrm{WO}_{3}-8 \mathrm{NbO}_{5 / 2}-5 \mathrm{LaO}_{3 / 2}-51 \mathrm{PO}_{5 / 2}$ glass (1Wglass), we successfully injected proton carriers with a concentration higher than $5 \times 10^{21} \mathrm{~cm}^{-3}$ and obtained a pure proton conductor [6]. However, the proton-conducting glass obtained ( $1 \mathrm{~W}$ glass after APS) was not stable and underwent deformation at temperatures higher than $250^{\circ} \mathrm{C}$.Therefore, the maximum proton conductivity was limited to $4.0 \times 10^{-4} \mathrm{Scm}^{-1}$ at $250{ }^{\circ} \mathrm{C}$. Extrapolation of the Arrhenius plot of its electrical conductivity suggests that the proton conductivity will reach $1 \times 10^{-2} \mathrm{Scm}^{-1}$ at $370{ }^{\circ} \mathrm{C}$ whenthe glass after APS becomes stable at $>370{ }^{\circ} \mathrm{C}[6]$.

The temperature, where the glass underwent deformation during electrical conductivity measurement, of the $1 \mathrm{~W}$ glass after APS is consistent with its glass transition temperature, $T_{\mathrm{g}}$, of $\sim 200{ }^{\circ} \mathrm{C}$ and its deformation temperature, $T_{\mathrm{d}}$, of $\sim 250{ }^{\circ} \mathrm{C}$. This indicates that the deformationwas caused by the significant decrease in viscosity of the glass at $>250{ }^{\circ} \mathrm{C}$. The reduction of viscosity of the glass induces the evaporation of $\mathrm{H}_{2} \mathrm{O}$ and/or phosphoric acid, i.e., deprotonation; and then, the proton conductivity of the glass is lost. One of the major advantages of glass electrolytes over crystal electrolytes is their compositional flexibility. This allowsfor an improvement in the thermal 
stability, i.e., suppression of the viscosity reduction and deprotonation, of the glass after APS upon optimizing the glass composition.

We thus studied three glasses, in which a portion of the $\mathrm{NaO}_{1 / 2}$ and/or the $\mathrm{PO}_{5 / 2}$ in the $1 \mathrm{~W}$ glass were substituted with $\mathrm{AlO}_{3 / 2}$ and/or $\mathrm{YO}_{3 / 2}$, to increase the thermal stability of the glass. The compositionswere: $35 \mathrm{NaO}_{1 / 2}-1 \mathrm{WO}_{3}-8 \mathrm{NbO}_{5 / 2}-5 \mathrm{LaO}_{3 / 2}-3 \mathrm{AlO}_{3 / 2}-48 \mathrm{PO}_{5 / 2}$ glass (1W-Al glass), $35 \mathrm{NaO}_{1 / 2}-1 \mathrm{WO}_{3}-8 \mathrm{NbO}_{5 / 2}-5 \mathrm{LaO}_{3 / 2}-3 \mathrm{YO}_{3 / 2}-48 \mathrm{PO}_{5 / 2}$ glass (1W-Y glass), and $30 \mathrm{NaO}_{1 / 2}-1 \mathrm{WO}_{3}-8 \mathrm{NbO}_{5 / 2}-5 \mathrm{LaO}_{3 / 2}-3 \mathrm{AlO}_{3 / 2}-3 \mathrm{YO}_{3 / 2}-50 \mathrm{PO}_{5 / 2}$ glass (1W-AlY glass). These were prepared and subjected to APS. Theirdeformation and deprotonation behaviors were studied by the thermal expansion and thermogravimetry (TG), respectively.The electrical conductivity after APS is discussed in terms of the mobility of the proton carriers.

\section{Experimental}

\subsection{Glass preparation}

The glassesdenoted $1 \mathrm{~W}, 1 \mathrm{~W}-\mathrm{Al}, 1 \mathrm{~W}-\mathrm{Y}$, and $1 \mathrm{~W}-\mathrm{AlY}$ were prepared by a conventional melt-quenching technique. The raw materials: $\mathrm{Na}_{2} \mathrm{CO}_{3}, \mathrm{WO}_{3}, \mathrm{Nb}_{2} \mathrm{O}_{5}, \mathrm{La}_{2} \mathrm{O}_{3}, \mathrm{Al}_{2} \mathrm{O}_{3}, \mathrm{Y}_{2} \mathrm{O}_{3}$, and $\mathrm{H}_{3} \mathrm{PO}_{4}$ were weighed and mixed.They were then melted in a platinum crucible for $1 \mathrm{~h}$ at $1400-1450{ }^{\circ} \mathrm{C}$ in air. The molten materials were poured into a cylindrical carbon mold with an inner diameter of $18 \mathrm{~mm}$. It was annealed at $420-450{ }^{\circ} \mathrm{C}$ for $10 \mathrm{~min}$ and subsequently cooled slowly to $350{ }^{\circ} \mathrm{C}$ at a cooling rate of $20^{\circ} \mathrm{C} \mathrm{h}^{-1}$. It wasthen cooled to $100{ }^{\circ} \mathrm{C}$ at a cooling rate of

$50{ }^{\circ} \mathrm{C} \mathrm{h}^{-1}$. The $T_{\mathrm{g}}$ and $T_{\mathrm{d}}$ of these glassesweredetermined using the thermal expansion curves recorded on a TMA/SS-6000 (SII, Japan).

\subsection{Alkali-proton substitution (APS)}

APS was applied to the prepared glasses using an APS apparatus (KDK-800, Kenix Co., Japan).The detailed configuration is described in our previous papers [4-6]. Disk-shaped glass 
plates witha diameter of $18 \mathrm{~mm}$ and a thickness of $1 \mathrm{~mm}$ were sliced from the cylindrical glass block and both surfaces were polished. A thin film of metallic palladium (Pd) with a thickness of approximately $0.2 \mu \mathrm{m}$ was deposited by magnetron sputtering onto one surface of the glass plate. The glass plate was then loaded into a holder made of quartz with the Pd-deposited surface facing upwards. The other face of the glass was positioned to enable contact with molten Sn under a $5 \%$ $\mathrm{H}_{2} / 95 \% \mathrm{~N}_{2}$ atmosphere. A DC bias of $5.0 \mathrm{~V}$ was applied between the Pd anode and the molten $\mathrm{Sn}$ cathode. The APS temperature and duration was: $310^{\circ} \mathrm{C}$ for $11 \mathrm{~h}, 345^{\circ} \mathrm{C}$ for $4 \mathrm{~h}, 335^{\circ} \mathrm{C}$ for $6 \mathrm{~h}$, and $355^{\circ} \mathrm{C}$ for $4 \mathrm{~h}$, respectively, for the $1 \mathrm{~W}, 1 \mathrm{~W}-\mathrm{Al}, 1 \mathrm{~W}-\mathrm{Y}$, and $1 \mathrm{~W}-\mathrm{AlY}$ glasses.

\subsection{Characterization}

TG analyses of the glasses after APSwere performed usinga TG/DTA6300 (SII, Japan).The thermal expansion curvesweremeasured using a TMA/SS-6000 (SII) to determine the $T_{\mathrm{g}}$ and the $T_{\mathrm{d}}$. The sodium concentration in the glass was determined using an energy-dispersive X-ray spectrometer (EDX; JED-2300, JEOL, Japan) attached to a scanning electron microscope (SEM; JSM-6335F, JEOL, Japan). The concentration of protons that formed OHgroups in the glass was determined by the absorbance of the $\mathrm{O}-\mathrm{H}$ stretching vibration, $v_{\mathrm{OH}}$, as recorded by a Fourier transform infrared (FTIR) spectrometer (FT-IR6100, JASCO, Japan) with an infrared microscope (IRT-5000, JASCO, Japan). The $\mathrm{OH}$ concentration, $n_{\mathrm{OH}}$ in $\mathrm{cm}^{-3}$, i.e., the proton concentration, was calculated from the maximum absorption intensity of $v_{\mathrm{OH}}, \alpha\left(v_{\mathrm{OH}}\right)$ in $\mathrm{cm}^{-1}$ using the following equation[7]:

$$
n_{\mathrm{OH}}=1.03 \times 10^{19} \times \alpha\left(v_{\mathrm{OH}}\right)
$$

Electrical conductivitiesat various temperatures were determined from the impedance spectra recorded using an impedance analyzer (HP4192A) under a dry 5\% $\mathrm{H}_{2} / 95 \% \mathrm{~N}_{2}$ atmosphere. Both surfaces of the glassplate after APS were polished again, because the glass surfaces were slightly roughed during APS. Then,Pd films were deposited again for the electrical conductivity and 
electromotive force (emf) measurements. The mean transport number of the protons was calculated from the emf of the hydrogen concentration cell with a structure of gas (I), Pd $\mid$ glass $\mid \mathrm{Pd}$, gas (II). Gas (I) was constant at $5 \% \mathrm{H}_{2} / 95 \% \mathrm{~N}_{2}$ and gas (II) was a mixture of $\mathrm{H}_{2}$ and $\mathrm{N}_{2}$ with various $\mathrm{H}_{2}$ concentrations from $0.2 \%$ to $5 \%$. The partial pressure of water, $P_{\mathrm{H} 2 \mathrm{O}}$, of gases (I) and (II) was fixed at $1.7 \times 10^{3} \mathrm{~Pa}$ and this was achieved by passing water at $15{ }^{\circ} \mathrm{C}$ to define the $P_{\mathrm{H} 2}$ and $P_{\mathrm{O} 2}$ in the atmosphere.

\section{Results and discussion}

Figure 1(a) shows TG analyses of the glass after APS together with those of the $35 \mathrm{NaO}_{1 / 2}-20 \mathrm{WO}_{3}-45 \mathrm{PO}_{5 / 2}(20 \mathrm{~W})$ and $8 \mathrm{WO}_{3}-35 \mathrm{NaO}_{1 / 2}-8 \mathrm{NbO}_{5 / 2}-5 \mathrm{LaO}_{3 / 2}-44 \mathrm{PO}_{1 / 2}$ (8W)glasses after APS $[4,5]$. The weights of the glasses began to decrease at $>300{ }^{\circ} \mathrm{C}$. These weight decreases can be attributedto deprotonation caused by the evaporation of $\mathrm{H}_{2} \mathrm{O}$ and/or phosphoric acid from the glasses. The temperatures indicated by the arrows in Fig. 1(a) are defined as the on-settemperature of deprotonation. Figure 1(b) shows the relationship between the on-set temperature of deprotonation and the $T_{\mathrm{g}}$ of the glasses before APS. As shownin the figure, the deprotonation starts at a higher temperature whenthe $T_{\mathrm{g}}$ of the glass before APSishigher.The $T_{\mathrm{g}}$ and $T_{\mathrm{d}}$ of the glasses before and after APS are summarized in Table 1 . Both $T_{\mathrm{g}}$ and $T_{\mathrm{d}}$ increaseupon theaddition of $\mathrm{AlO}_{3 / 2}$ and/or $\mathrm{YO}_{3 / 2}$ compared withthe $1 \mathrm{Wglass}$. The $T_{\mathrm{g}}$ and $T_{\mathrm{d}}$ of the $1 \mathrm{~W}-\mathrm{AlY}$ glass after APS were $80-90{ }^{\circ} \mathrm{C}$ higher than those of the $1 \mathrm{~W}$ glass. These results indicate that high thermalstability can be attained for the glass after APS when APS is applied to the glass with a high $T_{\mathrm{g}}$ before APS.

Figure 2 shows Arrhenius plots of the electrical conductivity of the glasses after APS.Electrical conductivity could be measured for the $1 \mathrm{~W}-\mathrm{Al}, 1 \mathrm{~W}-\mathrm{Y}$, and $1 \mathrm{~W}-\mathrm{AlY}$ glasses after APS up to $350{ }^{\circ} \mathrm{C}$ without softening and deformation as expected from their $T_{\mathrm{g}}$ and $T_{\mathrm{d}}$ values, whereas it could not be measured for the $1 \mathrm{~W}$ glass at $>250{ }^{\circ} \mathrm{C}$ because of softening and 
deformation. The thermal stability of the $1 \mathrm{~W}$ glass was successfully improved by $\mathrm{AlO}_{3 / 2}$ and/or $\mathrm{YO}_{3 / 2}$ addition. The mean proton transport number for those glasses wasfoundto be unity from the emf measurements.However, their proton conductivitieswere1-2 orders of magnitude lower than that of the $1 \mathrm{~W}$ glass [5]. The highest conductivity was $\sim 1 \times 10^{-3} \mathrm{Scm}^{-1}$ at $350{ }^{\circ} \mathrm{C}$ for the $1 \mathrm{~W}-\mathrm{Al}$ glass after APS, and we did not achievethe expectedconductivity of $>1 \times 10^{-2} \mathrm{Scm}^{-1}$ despite the thermal stability beingsuccessfully improved.

Table 2 summarizes the sodium and $\mathrm{OH}$ concentrations of the glasses before and after APS. The absolute values of the decreasing sodium concentration, $\Delta n_{\mathrm{Na}}$, and the increasing $\mathrm{OH}$ concentration, $\Delta n_{\mathrm{OH}}$, agree well with each other. This indicates that the sodium ions in the glass before APS were successfully substituted with protons after APS. The OH concentration after APS was6- $8 \times 10^{21} \mathrm{~cm}^{-3}$ for $1 \mathrm{~W}-\mathrm{Al}, 1 \mathrm{~W}-\mathrm{Y}$, and $1 \mathrm{~W}-\mathrm{AlY}$, and this valueisslightly higher than that of the1W glass after APS of $5 \times 10^{21} \mathrm{~cm}^{-3}$. Therefore, the decrease in proton conductivity that was induced by $\mathrm{AlO}_{3 / 2}$ and/or $\mathrm{YO}_{3 / 2}$ addition can be attributedto the reduced mobility of the proton carriers in the $1 \mathrm{~W}-\mathrm{Al}, 1 \mathrm{~W}-\mathrm{Y}$, and $1 \mathrm{~W}$-AlY glasses after APS. Table 3 summarizes the mobility of the proton carriers at $250{ }^{\circ} \mathrm{C}$ in the glasses after APS.These values were calculated assuming that all the protons that form OHgroups at room temperature, as detected by IR spectroscopy, become carriers at high temperature. It is evident that the mobility of the proton carriers is reduced by $1 / 20-1 / 50$ by the introduction of $\mathrm{AlO}_{3 / 2}$ and/or $\mathrm{YO}_{3 / 2}$ into the glass.

The following discussionexplains the reason for the mobility of the proton carriersbeingreduced by the introduction of $\mathrm{AlO}_{3 / 2}$ and/or $\mathrm{YO}_{3 / 2}$ into the $1 \mathrm{~W}$ glass, based on the IR spectra in $v_{\mathrm{OH}}$ region as shown in Fig. 3. For the $1 \mathrm{~W}$ glass that is before the introduction of $\mathrm{AlO}_{3 / 2}$ and/or $\mathrm{YO}_{3 / 2}$, an intense and broad $v_{\mathrm{OH}}$ band centered at $\sim 2900 \mathrm{~cm}^{-1}$ is observed. The broad band is slightly asymmetric and deconvoluted into an intense $2900 \mathrm{~cm}^{-1}$ band and a weak $3300 \mathrm{~cm}^{-1}$ band. Both thesebands are presentat a lower frequency than the $v_{\mathrm{OH}}$ band for the free $\mathrm{H}_{2} \mathrm{O}$ molecule at $3690 \mathrm{~cm}^{-1}$ [8].Therefore, the protons in the OHgroups form hydrogen bonds with the adjacent 
oxygen [8]. For the glasses containing $\mathrm{AlO}_{3 / 2}$ and/or $\mathrm{YO}_{3 / 2}$, the intensityof the band at 3300 $\mathrm{cm}^{-1}$ obviously increases compared with the glass without $\mathrm{AlO}_{3 / 2}$ and/or $\mathrm{YO}_{3 / 2}$. The mobility of the proton carriers decrease with an increase in theintensity ratio of the band at $2900 \mathrm{~cm}^{-1}$ to the band at $3300 \mathrm{~cm}^{-1}, I_{3300} / I_{2900}$, as indicated in Table 3 . This reduced mobility of the proton carriers can be attributed to the increase in protons that are tightly bound to oxygen, i.e., the formation of weak hydrogen bondings, as follows: When the concentration of protons that are tightly bound to oxygen is small, the protons can move without passing through the proton site, where the protons are tightly bound to oxygen. Therefore, the macroscopic proton mobility is determined by the protons that are loosely bound to oxygen. When the concentration of protons that are tightly bound to oxygen is large, the tightly bound proton site is involved in the conduction path, i.e, the protons cannot move over a long distance without passing through the tightly bound proton site. In this case, the macroscopic proton mobility is determined by the protons that are tightly bound to oxygen; as a result, the observed mobility of protons decreases as indicated in Table 3.The mechanismforthe strength of $\mathrm{O}-\mathrm{H}$ bonding beingsignificantlyaffected by the introduction of a small amount of $\mathrm{AlO}_{3 / 2}$ and/or $\mathrm{YO}_{3 / 2}$ is not clear.However, thischange must come from achange in the glass structure upon the introduction of $\mathrm{AlO}_{3 / 2}$ and/or $\mathrm{YO}_{3 / 2}$. Because there is no precedent foraglass containing such a high proton concentration at high temperatures, as is the case forthe studiedglasses, an understanding ofthe mobility of the proton carriersintheseglasses isdeficient at present. The relationship between the mobility of the proton carriers and the glass structure in the electrochemically proton-injected glasses will providevaluable information for thedesign of an optimal glass composition to achieve a simultaneoushigh protonic conductivity and high thermal stability.

\section{Summary}

In this study, we improved the thermal stability of the $1 \mathrm{~W}$ glass after APS by the introduction 
of a small amount of $\mathrm{AlO}_{3 / 2}$ and/or $\mathrm{YO}_{3 / 2}$. The obtained 1W-Al, 1W-Y,and 1W-AlY glasses are stable at $350{ }^{\circ} \mathrm{C}$, which is $100{ }^{\circ} \mathrm{C}$ higher than the stability limit of the $1 \mathrm{~W}$ glass. However, the mobility of the proton carriers in the $1 \mathrm{~W}-\mathrm{Al}, 1 \mathrm{~W}-\mathrm{Y}$, and $1 \mathrm{~W}-\mathrm{AlY}$ glasses are $1 / 20-1 / 50$ lower than that of the $1 \mathrm{~W}$ glass. Thisreduced mobility is attributed to anincrease inthe protons that are tightly bound to oxygen leading to the formation ofweak hydrogen bonding. This change in $\mathrm{O}-\mathrm{H}$ bond strength must come from a structural change in the glass, which is induced by the introduction of $\mathrm{AlO}_{3 / 2}$ and/or $\mathrm{YO}_{3 / 2}$. Understanding the relationship between the glass structure and proton mobility will provide information about the glass compositionsrequired toachievea simultaneous high proton carrier mobility and high thermal stabilityintheseglasses.

\section{Acknowledgment}

This work was supported in part by the Advanced Low Carbon Technology Research and Developing Program of the Japan Science and Technology Agency (JST-ALCA). 


\section{References}

[1] D. J. L. Brett, A. Atkinson, N. P. Brandon, S. J. Skinner, Chem. Soc. Rev. 37 (2008)1568-1578.

[2] B. Zhu, J. Power Sources 93(2001) 82-86.

[3] J. P. P. Huijsmans, F. P. F. Berkel, G. M. Christie, J. Power Sources 71 (1998) 107-110.

[4] T. Ishiyama, S. Suzuki, J. Nishii, T. Yamashita, H. Kawazoe, T. Omata, J. Electrochem. Soc. 160 (2013) E143-E147.

[5] T. Ishiyama, S. Suzuki, J. Nishii, T. Yamashita, H. Kawazoe, T. Omata, Solid State Ionics 262 (2014) 856-859.

[6] T. Ishiyama, J. Nishii, T. Yamashita, H. Kawazoe, T. Omata, J. Mater. Chem. A 2 (2014) $3940-3947$.

[7] Y. Abe, D. E. Clark, J. Mater. Sci. Lett. 9 (1990) 244-245.

[8] A. Novak, Struct. Bonding 18 (1974) 177-216. 


\section{Figure captions}

Figure 1.(a) TG curves of the glass after APS together with those of the $20 \mathrm{~W}$ and $8 \mathrm{~W}$ glasses after APS. (b) On-set temperatures for thedeprotonation of the glasses after APS as a function, and the $T_{\mathrm{g}}$ of the glasses before APS.

Figure 2. Arrhenius plots of the electrical conductivity of the glasses after APS. The mean proton transport numbers of the glasses were determined from the emfs of hydrogen concentration cells and are unity.

Figure 3.IR spectra of theOH stretching vibration, $v_{\mathrm{OH}}$, region of the glasses after APS. The thin lines are deconvoluted curves. 
Table 1 Glass transition temperatures, $T_{\mathrm{g}}$, and deformation temperatures, $T_{\mathrm{d}}$, of the glasses before and after APS.

\begin{tabular}{lcccc}
\hline \multirow{2}{*}{ Glass } & \multicolumn{2}{c}{ Before APS } & \multicolumn{2}{c}{ After APS } \\
& $T_{\mathrm{g}} /{ }^{\circ} \mathrm{C}$ & $T_{\mathrm{d}} /{ }^{\circ} \mathrm{C}$ & $T_{\mathrm{g}} /{ }^{\circ} \mathrm{C}$ & $T_{\mathrm{d}} /{ }^{\circ} \mathrm{C}$ \\
\hline \hline $1 \mathrm{~W}$ & 407 & 453 & 196 & 247 \\
$1 \mathrm{~W}-\mathrm{Al}$ & 457 & 499 & 224 & 290 \\
$1 \mathrm{~W}-\mathrm{Y}$ & 448 & 487 & 228 & 284 \\
$1 \mathrm{~W}-\mathrm{AlY}$ & 476 & 520 & 281 & 339 \\
\hline
\end{tabular}

Table 2 Sodium and $\mathrm{OH}$ concentrations, $n_{\mathrm{Na}}$ and $n_{\mathrm{OH}}$, of the glasses before and after APS and differences, $\Delta n$, in $n_{\mathrm{Na}}$ and $n_{\mathrm{OH}}$ before and after APS.

\begin{tabular}{lcccccc}
\hline \multirow{2}{*}{ Glass } & \multicolumn{2}{c}{ Sodium concentration $/ \mathrm{cm}^{-3}$} & \multicolumn{3}{c}{ OH concentration $/ \mathrm{cm}^{-3}$} \\
& $n_{\mathrm{Na} \text { (before APS })}$ & $n_{\mathrm{Na}}($ after APS $)$ & $\Delta n_{\mathrm{Na}}$ & $n_{\mathrm{OH}(\text { before APS })}$ & $n_{\mathrm{OH}}($ after APS $)$ & $\Delta n_{\mathrm{OH}}$ \\
\hline \hline $1 \mathrm{~W}$ & $9 \times 10^{21}$ & $3 \times 10^{21}$ & $-6 \times 10^{21}$ & $4 \times 10^{19}$ & $5 \times 10^{21}$ & $5 \times 10^{21}$ \\
$1 \mathrm{~W}-\mathrm{Al}$ & $9 \times 10^{21}$ & $2 \times 10^{21}$ & $-7 \times 10^{21}$ & $3 \times 10^{19}$ & $6 \times 10^{21}$ & $6 \times 10^{21}$ \\
$1 \mathrm{~W}-\mathrm{Y}$ & $9 \times 10^{21}$ & $1 \times 10^{21}$ & $-8 \times 10^{21}$ & $4 \times 10^{19}$ & $6 \times 10^{21}$ & $6 \times 10^{21}$ \\
$1 \mathrm{~W}-\mathrm{AlY}$ & $8 \times 10^{21}$ & $1 \times 10^{21}$ & $-8 \times 10^{21}$ & $4 \times 10^{19}$ & $8 \times 10^{21}$ & $8 \times 10^{21}$ \\
\hline
\end{tabular}

Table 3 Proton conductivity, $\sigma_{\mathrm{H}}$, proton carrier concentration, $n_{\mathrm{H}+}$, and mobility of the proton carriers, $\mu_{\mathrm{H}+}$, at $250{ }^{\circ} \mathrm{C}$ in the glasses after APS. All the protons that form OHgroups at room temperature are assumed to be proton carriers at $250{ }^{\circ} \mathrm{C} . I_{3300} / I_{2900}$ indicates the intensity ratio betweenthe $v_{\mathrm{OH}}$ band at $2900 \mathrm{~cm}^{-1}$ andthe $v_{\mathrm{OH}}$ band at $3300 \mathrm{~cm}^{-1}$ in IR spectra shown in Fig. 3 .

\begin{tabular}{lcccc}
\hline \multicolumn{1}{c}{ Glass } & $\sigma_{\mathrm{H}} / \mathrm{Scm}^{-1}$ & $n_{\mathrm{H}^{+}} / \mathrm{cm}^{-3}$ & $\begin{array}{c}\mu_{\mathrm{H}^{+}} / \\
\mathrm{cm}^{2} \mathrm{~V}^{-1} \mathrm{~s}^{-1}\end{array}$ & $I_{3300} / I_{2900}$ \\
\hline \hline $1 \mathrm{~W}$ & $3 \times 10^{-4}$ & $5 \times 10^{21}$ & $4 \times 10^{-7}$ & 0.24 \\
$1 \mathrm{~W}-\mathrm{Al}$ & $2 \times 10^{-5}$ & $6 \times 10^{21}$ & $2 \times 10^{-8}$ & 0.40 \\
$1 \mathrm{~W}-\mathrm{Y}$ & $8 \times 10^{-6}$ & $6 \times 10^{21}$ & $9 \times 10^{-9}$ & 0.72 \\
$1 \mathrm{~W}-\mathrm{AlY}$ & $9 \times 10^{-6}$ & $8 \times 10^{21}$ & $8 \times 10^{-9}$ & 1.1 \\
\hline
\end{tabular}


Figure 1a

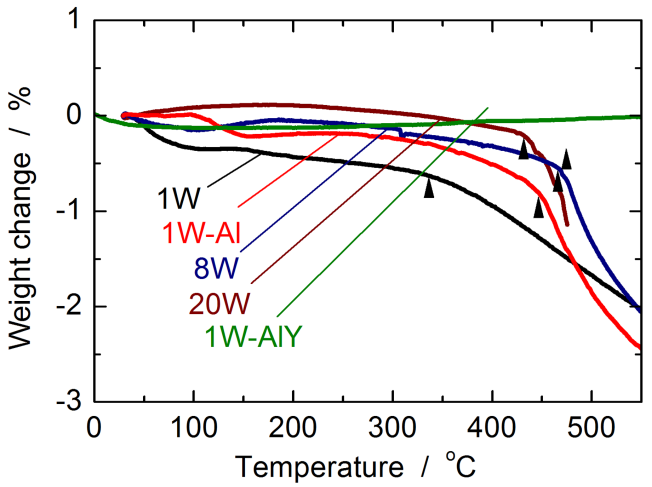


Figure 1b

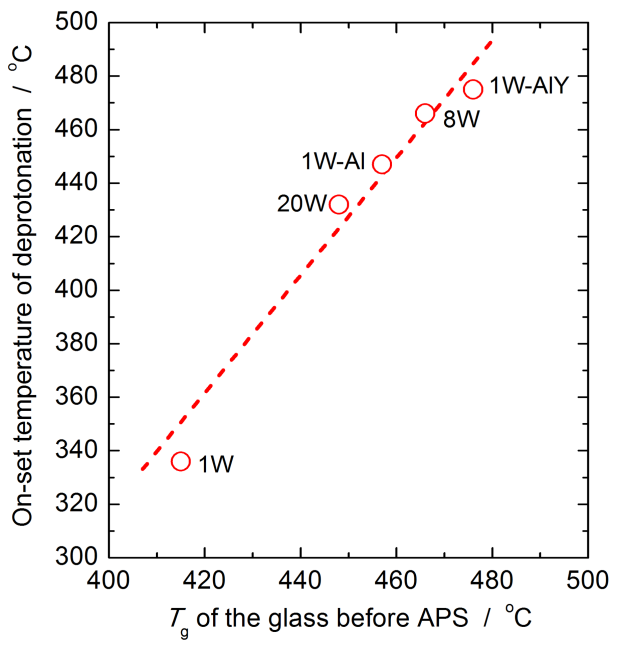


Figure 2

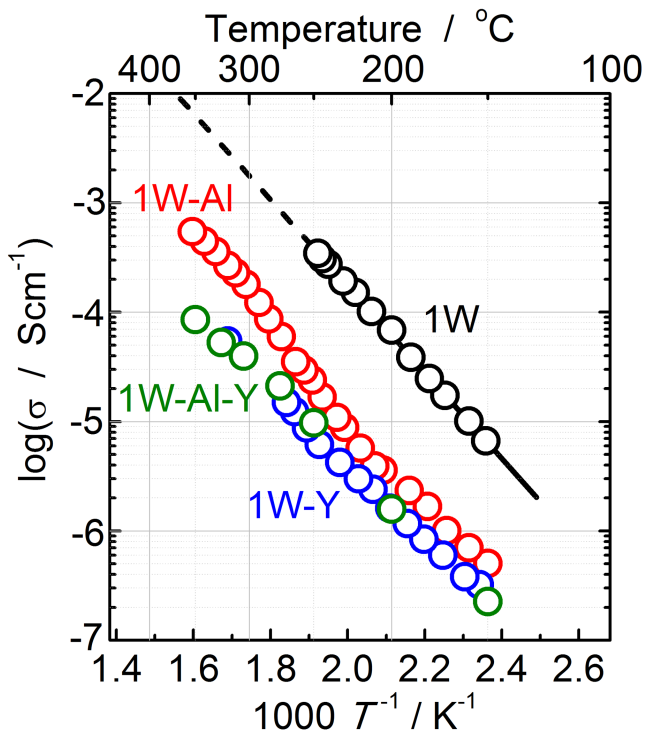


Figure 3

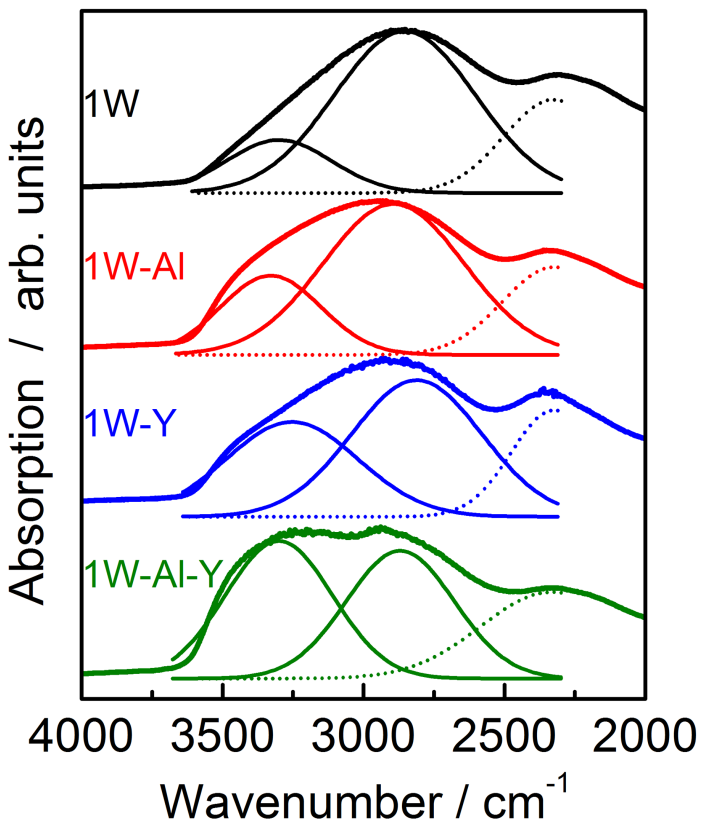

